October 2016

Volume 131 Number 5
Special Topic

Literature in the World

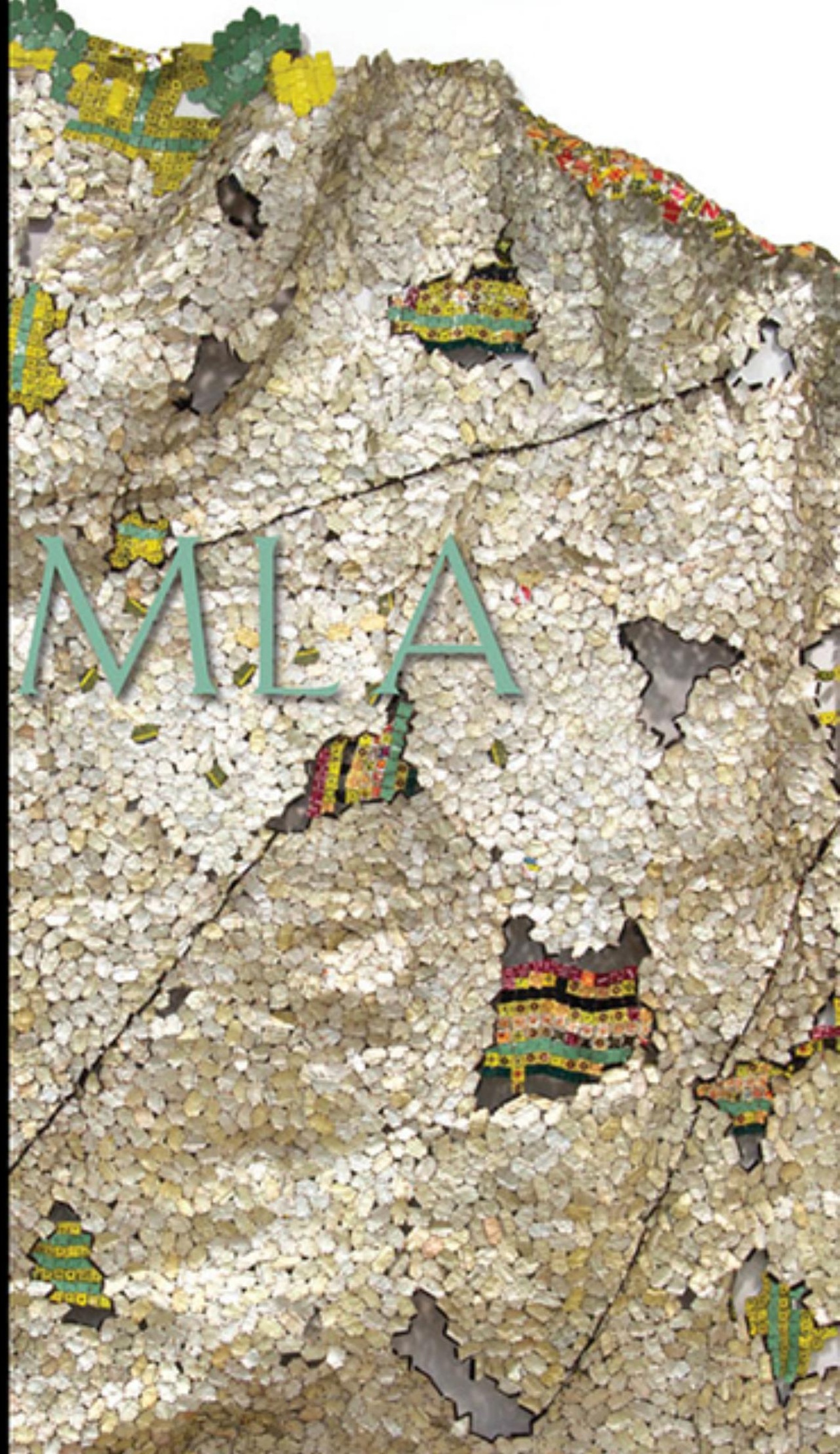

s. 


\section{October 2016}

Volume 131 Number 5

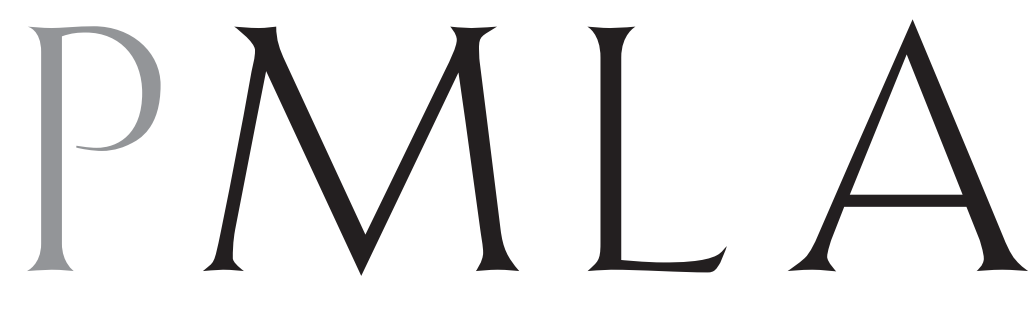

Publications of the Modern Language Association of America 
THE MODERN LANGUAGE ASSOCIATION OF AMERICA

[ Organized 1883, Incorporated 1900

\section{Officers for the Term Ending 8 January 2017}

President: Kwame Anthony Appiah New York University

First Vice President: Diana TaYlor New York University

Second Vice President: ANNE RugGLES Gere

University of Michigan, Ann Arbor

Executive Director: Rosemary G. FeAL

\section{Executive Council}

\author{
FOR THE TERM ENDING 8 JANUARY 2017 \\ DoNALD E. HALL \\ Lehigh University \\ Paula M. Krebs \\ Bridgewater State University \\ Elizabeth Schwartz Crane \\ Santa Rosa, CA
}

FOR THE TERM ENDING 7 JANUARY 2018

Brian Croxall

Brown University

Gaurav G. Desai

University of Michigan, Ann Arbor

Margaret R. Higonnet

University of Connecticut, Storrs

Tracy Denean Sharpley-Whiting

Vanderbilt University

FOR THE TERM ENDING 6 JANUARY 2019

EMILY APTER

New York University

David Palumbo-Liu

Stanford University

VICKY UNRUH

University of Kansas

FOR THE TERM ENDING 12 JANUARY 2020

ANGELIKA BAMMER

Emory University

LENORA HANSON

University of Wisconsin, Madison

David Tse-Chien PaN

University of California, Irvine

Rafael A. Ramirez Mendoza

University of California, Los Angeles

\section{Trustees of Invested Funds}

Malcolm B. Smith (Managing Trustee) New York, New York

Domna C. Stanton

New York, New York

CATHARINE R. STIMPSON New York, New York
PMLA (ISSN 0030-8129) is published five times a year, in January, March, May, September, and October, by the Modern Language Association of America. Membership in the association is open to persons who are professionally interested in the modern languages and literatures. Annual (calendar-year) dues, which include subscription to $P M L A$, are $\$ 23$ for graduate student members (up to a maximum of seven years) and are based on income for regular members: income under $\$ 15,000, \$ 28$; income $\$ 15,000$ $\$ 20,000, \$ 46$; income $\$ 20,000-\$ 30,000, \$ 56$; income $\$ 30,000-\$ 40,000, \$ 79$; income $\$ 40,000-\$ 50,000$ $\$ 94$; income $\$ 50,000-\$ 60,000, \$ 112$; income $\$ 60,000-\$ 70,000, \$ 130$; income $\$ 70,000-\$ 80,000, \$ 145$; income $\$ 80,000-\$ 100,000, \$ 163$; income $\$ 100,000-\$ 120,000, \$ 187$; income $\$ 120,000-\$ 140,000, \$ 210$; in come $\$ 140,000-\$ 160,000, \$ 232$; income $\$ 160,000-\$ 180,000, \$ 260$; income $\$ 180,000-\$ 200,000$, $\$ 289$; in come over $\$ 200,000, \$ 317$. Joint membership, which provides one copy of the January, March, May, and October issues of PMLA but two copies of all other publications, is available to two individuals sharing the same household. The dues for a joint membership are $\$ 46$ above the dues that would be paid by the higher-income member alone. Foreign members pay the same as regular members (use the Americandollar equivalent to ascertain the dues category). Membership applications are available on request and at the MLA Web site (www.mla.org).

For libraries and other institutions, a subscription in 2016 to the electronic format of PMLA alone is $\$ 200$ and to the print and electronic formats is \$220 (domestic and Canadian) or \$250 (foreign). Subscriptions also include online access to the 2002-15 volumes. Agents deduct four percent as their fee. Claims for undelivered issues will be honored if they are received within six months of the publication date; thereafter the single-issue price will be charged. To order an institutional subscription, call or write the Member and Administrative Services Office of the association (646 576-5166; subscrip@mla.org).

Single copies of the January, March, May, and October issues can be purchased for $\$ 12$ each; the September (Program) issue is $\$ 35$. Issues for the current year and the previous one are available at the MLA Bookstore (www.mla.org/store/CID70) and from the Member and Administrative Services Office of the association (646 576-5161; bookorders@mla.org).

An online archive of PMLA issues from 1884 to 2010 is available through JSTOR (www.jstor.org).

Volumes up to 2000 can be obtained on microfilm from NA Publishing, Inc. (800 420-6272; info@ napubco.com; napubco.com/periodicals-on-microform/)

The office of publication and editorial offices are located at 85 Broad Street, suite 500, New York, NY 10004-2434 (646 576-5000; pmlasubmissions@mla.org).

All communications concerning membership, including change-of-address notifications, should be sent to the Member and Administrative Services Office, MLA, 85 Broad Street, suite 500, New York, NY 10004-2434 (646 576-5151; membership@mla.org). If a change of address also involves a change of institutional affiliation or a new e-mail address, that office should be informed of this fact at the same time.

Periodicals postage paid at New York, NY, and at additional mailing offices.

(c) 2016 by The Modern Language Association of America. All rights reserved. Printed in the United States of America.

MLA and the MODERN LANGUAGE ASSOCIATION are trademarks owned by the Modern Language Association of America.

Library of Congress Catalog Card Number 12-32040. United States Postal Service Number 449-660. POSTMASTER: Send address changes to PMLA, Member and Customer Services Office, MLA, 85 Broad Street, suite 500, New York, NY 10004-2434. 


\section{Contents}

1190 Submitting Manuscripts to PMLA

1190 Forthcoming in PMLA

1191 Features in PMLA

Special Topic: Literature in the World

Coordinated by Simon Gikandi

1193 Introduction-Another Way in the World

SimON GiKandi

1207 That Which Is Casually Called a Language

Robert J. C. Young

1222 Literary Routes: Migration, Islands, and the Creative Economy

Françoise Lionnet and Emmanuel Bruno Jean-François

1239 How Mariama Bâ Became World Literature: Translation and the Legibility of Feminist Critique

TOBIAS WARNER

1256 Marianne Moore's Postwar Fables and the Politics of Indirection

Emily Setina

$1274 f$

YASSER ELHARIRY

1284 The Pícaro at War: Vernacular Language and Violent Conflict in Grimmelshausen and Saro-Wiwa

Philip Joseph

1299 Regionalizing the Planet: Horizons of the Introverted Novel at World Literature's End

TAYlor A. Eggan

1316 Language, Ethnicity, and the Politics of Literary Taxonomy: Ng Kim Chew and Mahua Literature CARLOS Rojas

1328 Atlantic and Other Worlds: Critique and Utopia in Postcolonial Historical Fiction

Greg Forter
PUBLICATIONS OF THE MODERN LANGUAGE ASSOCIATION OF AMERICA

[ Published five times a year $]$

Volumes Online

VOLS. 1-125 (1884-2010), JSTOR

VoLs. 117-31 (2002-16), MLAJournals.org

INDEX

Vols. 1-131 (1884-2016)

MLA International Bibliography

Editor

WAi CHeE Dimock

Yale University

Managing Editor

KathleEN FitzPatrick

Head of Periodical Publications

SARA PASTEI

Senior Editor

BARNEY LATIMER

Assistant Editors

Christiane Angeli

JOHN D. GOLBACH

JENNIFER A. RAPPAPORT

Advertising Manager and Submissions Associate

ANNABEL SCHNEIDER

Editorial Assistant

RAFAEL FonseCA

Editorial Board

Colleen Glenney Boggs, 2018

Dartmouth College

Alison Booth, 2017

University of Virginia

Vilashini CoOppan, 2018

University of California, Santa Cruz

STEPHANIE SANDLER, 2017 Harvard University

Elzbieta SklodowsKa, 2017

Washington University in St. Louis

Dominic R. Thomas, 2018

University of California, Los Angeles

Advisory Committee

IDELbER V. AVELAR, 2019 Tulane University

DaVid J. BARThOlOMAE, 2017 University of Pittsburgh

RALPH BAUER, 2019

University of Maryland, College Park

Karen E. BeCKMan, 2019

University of Pennsylvania

Heather Blurton, 2018

University of California, Santa Barbara

Edyta M. BoJanOWSKa, 2019

Rutgers University, New Brunswick

CARINe Bourget, 2018

University of Arizona, Tucson

SAMUel CoHen, 2017

University of Missouri, Columbia

William A. Cohen, 2018

University of Maryland, College Park

Ana Corbalan, 2017

University of Alabama, Tuscaloosa

Tyler Curtain, 2017

University of North Carolina, Chapel Hill (continued) 
Advisory Committee (continued)

Carolyn DinshaW, 2019 New York University

William E. Egginton, 2017 Johns Hopkins University

Daylanne K. English, 2018 Macalester College

Cristina Ferreira-Pinto Bailey, 2017

Washington and Lee University

Andrea Marie Frisch, 2017

University of Maryland, College Park

Regenia GAGNiER, 2019 University of Exeter

Fred L. Gardaphe, 2019

Queens College, City University of New York

Christina GerhardT, 2019

University of Hawai' $i$, Mānoa

Tobias B. Gregory, 2017

Catholic University of America

Robert J. GRIFFIN, 2019

Texas A\&M University, College Station

Corrinne Harol, 2018 University of Alberta

WAÏL S. HASSAN, 2017

New York University, Abu Dhabi

SCOTT HerRING, 2017

Indiana University, Bloomington

Alison S. JAmes, 2017

University of Chicago

JILL M. LANE, 2018

New York University

SEAN LATHAM, 2018 University of Tulsa

NaOmi Iliana Mandel, 2018

University of Rhode Island TOM Mole, 2018 University of Edinburgh

JAmes A. PARENTE, 2019 University of Minnesota, Twin Cities

JuAn EduARdo Poblete, 2017

University of California, Santa Cruz ATo QUAYSON, 2018 University of Toronto

JEAN-MiChel RaBATÉ, 2019 University of Pennsylvania JILL RoBBINS, 2018

University of California, Merced

ElizabeTH SAUER, 2018 Brock University

JoHN L. SCHILB, 2017

Indiana University, Bloomington

Ken Seigneurie, 2018

Simon Fraser University

Linda M. Shires, 2017

Stern College, Yeshiva University

Garrett A. Sullivan, 2018

Penn State University, University Park

Anthony Julian TAMBURRI, 2019

Queens College, City University of New York

Jane C. Tylus, 2019

New York University

Sharon A. Willis, 2018

University of Rochester

Heather Willis Allen, 2017

University of Wisconsin, Madison JiWEI XIAO, 2018 Fairfield University

Michael G. Ziser, 2019

University of California, Davis
1344 The Digital Ukumbi: New Terrains in Swahili Identity and Poetic Dialogue

Meg Arenberg

\section{talks from the convention}

1361 Unsettling World Literature

ANNA BRICKHOUSE

1372 The Scale of Global Modernisms: Imperial, National, Regional, Local HARSHA RAM

\section{theories and methodologies}

1386 Writing World Literature: Approaches from the Maghreb

Jane Hiddleston

1396 World Literature, by Any Other Name?

RAJAGOPALAN RADHAKRISHNAN

1405 Literatures of the World: An Inquiry

S. SHANKAR

1414 Against Historicist Fundamentalism

ERIC Hayot

1423 Surprise Me If You Can

Nirvana TaNoukHi

1435 Translational Literature and the Pleasures of Exile

WaÏl S. Hassan

1444 Thoughts on Writing Literary History: The Case of the Sri Lankan Malays

Ronit RicCI

1452 Lot's Wife Syndrome and Double Publics in South Africa

Grace A. Musila

the changing profession

1462 African Literature in the World: A Teacher's Report Akin Adesokan

1471 The Work of Teaching Literature in the Age of Mechanical Education Raphael Dalleo

1480 Literary Debt

Elaine Freedgood

1489 Talking French

Gerald Prince 
$131 \cdot 5]$

1495 The Tragic Critic after 9/11

JenNifer Wallace

1504 Macondo and Quimbaya in Mexico

Lois Parkinson Zamora

\section{correspondents at large}

1515 Teaching the Armenian Genocide in Turkey: Curriculum, Methods, and Sources

HÜLYA ADAK

1519 Phenomenology of Passage

Meena Alexander

1523 Teaching Literature under the Volcano

Nair María Anaya-Ferreira

1527 English in Hong Kong

Sharanya Jayawickrama

1531 Personal Reflections on Teaching Literature

Susan Nalugwa Kiguli

1535 The Land without the Canon Wars: Language, Literature, and New Freedoms in Myanmar

Amy K. Levin

1540 Neocoductive Ruminations

Terri Ochiagha

1544 Literature in the World: A View from Cape Town

Meg Samuelson

1548 The Nairobi Tradition of Literature

Godwin SIUNDU

1552 A Bicultural Education

Mark Williams

1557 FORUM

Heather Dubrow, Andrew Kopec

1561 Minutes of the MLA Executive Council

1570 In Memoriam

1572 Index of Advertisers

1590 Abstracts

Cover: Detail of El Anatsui, Another Place, 2014. Found aluminum and copper wire, $111 \frac{112}{2}$ $\times 112$ in. (C) El Anatsui. Courtesy of the artist and the Jack Shainman Gallery, New York. 